\title{
The EDC3 chronology for the EPICA Dome C ice core
}

\author{
F. Parrenin ${ }^{1}$, J.-M. Barnola ${ }^{1}$, J. Beer ${ }^{2}$, T. Blunier ${ }^{3}$, E. Castellano ${ }^{4}$, J. Chappellaz ${ }^{1}$, G. Dreyfus ${ }^{5}$, H. Fischer ${ }^{6}$, S. Fujita ${ }^{7}$, \\ J. Jouzel $^{5}$, K. Kawamura ${ }^{8}$, B. Lemieux-Dudon ${ }^{1}$, L. Loulergue ${ }^{1}$, V. Masson-Delmotte ${ }^{5}$, B. Narcisi ${ }^{9}$, J.-R. Petit ${ }^{1}$, \\ G. Raisbeck $^{10}$, D. Raynaud ${ }^{1}$, U. Ruth ${ }^{6}$, J. Schwander ${ }^{3}$, M. Severi ${ }^{4}$, R. Spahni ${ }^{3}$, J. P. Steffensen ${ }^{11}$, A. Svensson ${ }^{11}$, \\ R. Udisti ${ }^{4}$, C. Waelbroeck ${ }^{1}$, and E. Wolff ${ }^{12}$ \\ ${ }^{1}$ Laboratoire de Glaciologie et Géophysique de l'Environnement, CNRS and Joseph Fourier University, Grenoble, France \\ ${ }^{2}$ Department of Surface Waters, EAWAG, Dübendorf, Switzerland \\ ${ }^{3}$ Climate and Environmental Physics, Physics Institute, University of Bern, Bern, Switzerland \\ ${ }^{4}$ Department of Chemistry, University of Florence, Florence, Italy \\ ${ }^{5}$ Laboratoire des Sciences du Climat et de l'Environnement, IPSL/CEA/CNRS/UVSQ, Gif-Sur-Yvette, France \\ ${ }^{6}$ Alfred-Wegener-Institute for Polar and Marine Research, Bremerhaven, Germany \\ ${ }^{7}$ National Institute of Polar Research, Research Organization of Information and Systems (ROIS), Tokyo, Japan \\ ${ }^{8}$ Center for Atmospheric and Oceanic Studies Graduate School of Science, Tohoku University, Sendai, Japan \\ ${ }^{9}$ ENEA, C. R. Casaccia, Roma, Italy \\ ${ }^{10} \mathrm{CSNSM} / \mathrm{IN} 2 \mathrm{P} 3 / \mathrm{CNRS}$, Orsay, France \\ ${ }^{11}$ Niels Bohr Institute, University of Copenhagen, Copenhagen, Denmark \\ ${ }^{12}$ British Antarctic Survey, Cambridge, UK
}

Received: 20 February 2007 - Published in Clim. Past Discuss.: 12 March 2007

Revised: 4 June 2007 - Accepted: 24 July 2007 - Published: 17 August 2007

\begin{abstract}
The EPICA (European Project for Ice Coring in Antarctica) Dome C drilling in East Antarctica has now been completed to a depth of $3260 \mathrm{~m}$, at only a few meters above bedrock. Here we present the new EDC3 chronology, which is based on the use of 1) a snow accumulation and mechanical flow model, and 2) a set of independent age markers along the core. These are obtained by pattern matching of recorded parameters to either absolutely dated paleoclimatic records, or to insolation variations. We show that this new time scale is in excellent agreement with the Dome Fuji and Vostok ice core time scales back to $100 \mathrm{kyr}$ within $1 \mathrm{kyr}$. Discrepancies larger than $3 \mathrm{kyr}$ arise during MIS 5.4, 5.5 and 6, which points to anomalies in either snow accumulation or mechanical flow during these time periods. We estimate that EDC3 gives accurate event durations within $20 \%(2 \sigma)$ back to MIS11 and accurate absolute ages with a maximum uncertainty of 6 kyr back to $800 \mathrm{kyr}$.
\end{abstract}

\section{Introduction}

The EPICA project has provided two records in East Antarctica, one at Dome C (EDC, EPICA community members, 2004), and one in the Dronning Maud Land area (EDML,

Correspondence to: F. Parrenin

(parrenin@ujf-grenoble.fr)
EPICA community members, 2006). The completion of the Dome $\mathrm{C}$ core was delayed when the first drilling became stuck at $788 \mathrm{~m}$ in 1999. This shorter EDC96 core provided $45 \mathrm{kyr}$ of paleoclimatic reconstructions (e.g., Jouzel et al., 2001; Monnin et al., 2001). The next EDC99 drilling was voluntarily stopped at a depth of $3260 \mathrm{~m}$, about $15 \mathrm{~m}$ above bedrock, above which seismic soundings suggest the presence of melt water. EDC provides the longest in time ice core record available so far, with so far $\sim 740 \mathrm{kyr}$ records of Antarctic temperature (EPICA community members, 2004) and chemical impurities in Antarctica (Wolff et al., 2006), and $\sim 650$ kyr records of atmospheric composition (Siegenthaler et al., 2005; Spahni et al., 2005). All these records are currently being extended to $800 \mathrm{kyr}$.

An accurate age scale is the basis for the interpretation of paleoclimatic records. We distinguish different types of accuracies. First, age scales need to be accurate in terms of absolute ages: we want the estimated age at a certain depth to be as close as possible to the real age (with an accuracy expressed in yr). This absolute accuracy is crucial when examining the phasing of two absolutely dated paleoclimatic records, and with insolation variations calculated by modelling of planet movements in the past (Laskar, 1990). For example, the insolation/climate phase relationship has been studied for terminations I and II thanks to accurate absolute age scales (Jouzel et al., 1995; Henderson and Slowey, 2000).

Published by Copernicus Publications on behalf of the European Geosciences Union. 
Second, sequences of events can be analysed in detail without absolutely perfect age scales, provided that the studied records are stratigraphically linked. Here a relative age scale, (with an accuracy expressed in years) suffices. For example, the phasing between Antarctic temperature and $\mathrm{CO}_{2}$ variations during the last deglaciation has been obtained from the Dome $\mathrm{C}$ core by estimating the ice/gas bubbles age difference (Monnin et al., 2001). Other examples include the phasing between Greenland and Antarctic temperature during the last glacial period obtained by a synchronisation of those records with the $\mathrm{CH}_{4}$ atmospheric composition, which varies in phase at both poles (Blunier et al., 1998; EPICA community members, 2006). Third and finally, the last important accuracy is in the duration of climatic events (expressed in per cent). Indeed, this duration is characteristic of the climatic mechanisms involved, and will impact the frequency analysis of the records. We can cite as an example the duration and pacing of the so-called Dansgaard-Oeschger (D-O) events during the last glacial period which has been extensively studied (e.g., Schulz, 2002).

In the absence of radiochronologic constraints, numerous methods have been developed to date ice cores. They fall into 4 categories: (1) counting of layers representing a known time interval, e.g. annual layers, (2) ice flow modelling, (3) wiggle matching on other precisely dated time series, in particular insolation variations, and (4) use of climate independent age markers, like volcanic eruptions.

Ice flow modelling has been historically used to date ice cores from Greenland and Antarctica. A one-dimensional flow model was first applied to Camp Century (Dansgaard and Johnsen, 1969), and later to GRIP (Johnsen and Dansgaard, 1992; Johnsen et al., 2001). The Camp Century, Dye- 3 and GISP2 cores were also interpreted by matching the oxygen 18 isotope record of ice or air bubbles to the SPECMAP stack (Dansgaard et al., 1985; Bender et al., 1994), which is itself orbitally tuned. The GISP2 core was also dated with annual layer counting (Alley et al., 1997). In Antarctica, two-dimensional flow models were applied to the along-flow (non-dome) drilling sites of Byrd (Johnsen et al., 1972) and Vostok (Lorius et al., 1985; Parrenin et al., 2004). Annual layers were counted back to the LGM at Byrd (Hammer et al., 1994). The Vostok ice core has also been dated by matching to the orbital SPECMAP scale (Bender et al., 1994), or directly to insolation variations (Waelbroeck et al., 1995; Shackleton, 2000). More recently, one dimensional flow modelling controlled by other dating methods was applied to the EPICA Dome C ice core (EDC1, Schwander et al., 2001; EDC2, EPICA community members, 2004) and Dome Fuji ice cores (Watanabe et al., 2003).

All the above dating methods have advantages and drawbacks. Layer counting (Andersen et al., 2007) and ice flow modelling (Parrenin et al., 2006) are accurate in terms of event durations because they are based on the evaluation of the annual layer thickness. On the other hand, errors cumulate and the accuracy on absolute ages decreases with depth.
The new layer-counted chronology for Greenland (GICC05, Vinther et al., 2006; Rasmussen et al., 2006; Andersen et al., 2006; Svensson et al., 2006) uses an improved multiparameter counting approach, and currently extends back to around $42 \mathrm{kyr}$ BP with a maximum counting error of 4 to $7 \%$ during the last glacial period. Unfortunately, layer counting is not feasible in central Antarctica where annual cycles are barely distinguishable (Ekaykin et al., 2002).

Comparison of paleoclimatic records to insolation variations (so-called orbital tuning methods) are generally applicable to a whole ice core, as long as the stratigraphy is preserved (e.g., Martinson et al., 1987; Dreyfus et al., 2007). On the other hand: (1) the accuracy in terms of event durations is poor, (2) the accuracy in terms of absolute ages is limited by the hypothesis of a constant phasing between the climatic record used for the orbital tuning procedure and the insolation variations (and, by definition, does not allow one to infer this phasing). The advantage is that the achieved accuracy does not decrease with depth (assuming the underlying mechanism stays constant). As a consequence, it is currently the most precise method to date the bottom of deep ice cores. Recently, the search for local insolation proxies in ice cores as, e.g. the $\mathrm{O}_{2} / \mathrm{N}_{2}$ ratio (Bender et al., 2002; Kawamura et al., 2007) or the air content record (Raynaud et al., 2007) has opened new prospects for eliminating the reliance on this hypothesis of constant insolation/climate phase, potentially allowing an accuracy within $1 \mathrm{kyr}$ to be achieved in the coming years.

Precisely dated volcanic horizons provide important age markers. This is the case for the last millenium (Traufetter et al., 2004), but beyond that limit, only a few of them have accurate absolute ages (Narcisi et al., 2006). In Antarctic ice cores, comparison to absolutely dated paleoclimatic records is particularly relevant for the dating of the D-O events, which have been accurately dated in several archives, and whose rapid transitions can be localized with a high accuracy in the Antarctic $\mathrm{CH}_{4}$ record. The transfer of those age markers to the Antarctic ice matrix requires the evaluation of the ice/gas age difference with a firn densification model (e.g., Goujon et al., 2003, and references therein).

In this article, we present EDC3, the new $800 \mathrm{kyr}$ age scale of the EPICA Dome $\mathrm{C}$ ice core, which is generated using a combination of various age markers and a glaciological model. It is constructed in three steps. First, an age scale is created by applying an ice flow model at Dome C. Independent age markers are used to control several poorly known parameters of this model (such as the conditions at the base of the glacier), through an inverse method. Second, the age scale is synchronised onto the new Greenlandic GICC05 age scale over three time periods: the last $6 \mathrm{kyr}$, the last deglaciation, and the Laschamp event (around $41 \mathrm{kyr}$ BP). Third, the age scale is corrected in the bottom $\sim 500 \mathrm{~m}$ (corresponding to the time period 400-800 kyr BP), where the model is unable to capture the complex ice flow pattern.

In Sect. 2, we first present the different age markers that 
can be found in the EDC ice core. We then describe in Sect. 3 the construction of EDC3. In Sect. 4, we compare it with other age scales from the late Quaternary. Finally, we discuss the accuracies of this new time scale in Sect. 5.

In this paper, the notation "yr BP" refers to "years before AD1950".

\section{Age markers}

In this section, we describe the dated horizons (so-called age markers) that can be derived from the EDC ice core.

\subsection{Dated volcanic eruptions during the last millenium}

Using sulphate data (Castellano et al., 2005), several volcanic eruptions of known age have been identified in the EDC96 ice core during the Holocene. Among these, only a few of the most recent are independently absolutely dated (Traufetter et al., 2004): Krakatau ${ }^{1}, 8.35$ m, AD1884 \pm 1 ; Tambora, $12.34 \mathrm{~m}, \mathrm{AD} 1816 \pm 1$; Huaynaputina, $23.20 \mathrm{~m}, \mathrm{AD} 1601 \pm 1$; Kuwae, $29.77 \mathrm{~m}, \mathrm{AD} 1460 \pm 5$; Unknown (El Chichon?), $38.12 \mathrm{~m}, \mathrm{AD} 1259 \pm 5$; Unidentified, $39.22 \mathrm{~m}, \mathrm{AD} 1228 \pm 5$; Unknown, $41.52 \mathrm{~m}, \mathrm{AD} 1171 \pm 6$.

2.2 Synchronisation onto GICC05 and INTCAL with ${ }^{10} \mathrm{Be}$ for the last $6 \mathrm{kyr}$

${ }^{10} \mathrm{Be}$ and ${ }^{14} \mathrm{C}$ are cosmogenic radionuclides, and their production rates are modulated by solar activity and by the strength of the Earth's magnetic field. Therefore ${ }^{10} \mathrm{Be}$ records in Greenland and Antarctica, as well as atmospheric ${ }^{14} \mathrm{C}$ reconstructions (INTCAL, Reimer et al., 2004) show common variations.

Three methods were used independently to construct age scales for EDC over the last $6 \mathrm{kyr}$. The first two are obtained by wiggle matching the EDML ${ }^{10} \mathrm{Be}$ record to either the GRIP ${ }^{10} \mathrm{Be}$ record dated by layer counting (GICC05, Vinther et al., 2006), or with the INTCAL atmospheric ${ }^{14} \mathrm{C}$ reconstruction (Reimer et al., 2004). These age scales have been transferred to EDC96 by volcanic synchronisation (Severi et al., 2007). The third time scale is obtained by wiggle matching to the Vostok ${ }^{10} \mathrm{Be}$ record with INTCAL atmospheric ${ }^{14} \mathrm{C}$ reconstructions (Raisbeck et al., 1998). The resulting Vostok age scale (more precisely the VK-BH1 core age scale) was then transferred to EDC96 via the VK-BH7 core by volcanic matching (Udisti et al., 2004).

We derive two age markers from these chronologies, at periods of large ${ }^{10} \mathrm{Be}$ and ${ }^{14} \mathrm{C}$ variations (when the synchronisation is robust). The three chronologies give similar ages within 30 years for these two periods and we calculated average ages of : $2716 \mathrm{yr}$ BP and $5279 \mathrm{yr}$ BP for the age markers at $107.83 \mathrm{~m}$ and $181.13 \mathrm{~m}$, respectively.

\footnotetext{
${ }^{1}$ The identification of this volcanic eruption has actually been revised since the study by Castellano et al. (2005).
}

\subsection{Match to GICC05 with $\mathrm{CH}_{4}$ during the last deglaciation}

During the last deglaciation, synchronisation to the NGRIP GICC05 chronology (Rasmussen et al., 2006) is possible with the transitions (Björck et al., 1998) that are common to the Greenland and Antarctic high resolution methane records, and the Greenland climate record (Severinghaus and Brook, 1999): GS-2a/GI-1e (Oldest Dryas/Bølling), GI-1a/GS-1 (Allerød/Younger Dryas) and GS-1/Holocene (Younger Dryas/Holocene). In that way an age for the $\mathrm{CH}_{4}$ transitions can be obtained. This age for the gas record then has to be transferred to an age for the ice. However, the uncertainty in the estimation of this age difference ( $\Delta$ age) is large at EDC because of the low accumulation rate and the low temperature (typical model estimates of $\Delta$ age at EDC are $2200 \mathrm{yr}$ for the Holocene and $5500 \mathrm{yr}$ for the LGM). This forces us to make a detour via the EDML ice core where accumulation rate and temperature are higher (typical model estimates of $\triangle$ age at EDML are $700 \mathrm{yr}$ for the Holocene and $1800 \mathrm{yr}$ for the LGM). For the rapid warmings at the GS-2a/GI-1e and GS-1/Holocene transitions, the EDML $\mathrm{CH}_{4}$ data were matched to the NGRIP stable isotope record (NGRIP project members, 2004). The corresponding GICC05 ages were transferred first from the EDML gas depth-scale to the EDML ice depth-scale by subtracting the calculated $\Delta$ depth (depth difference between gas bubbles and ice with the same age). $\Delta$ depth was obtained by multiplying the modelled close off depth (in ice equivalent, Loulergue et al., 2007) with the EDML mechanical thinning function (Huybrechts et al., 2007). This age was further transferred to EDC via the volcanic match between both cores (Severi et al., 2007).

The two derived age markers are $11.65 \pm 0.32$ and $14.64 \pm 0.35 \mathrm{kyr}$ BP for respectively $355.34 \mathrm{~m}$ and $421.15 \mathrm{~m}$ EDC96-depth. The uncertainty is estimated as the root mean square sum of the GICC05 age error (the number of uncertain layers given by Rasmussen et al., 2006, is taken as $2 \sigma$ ) and of a $300 \mathrm{yr} 2 \sigma$ uncertainty resulting from the uncertainty in the $\Delta$ depth estimate at EDML $(2 \sigma=10 \mathrm{~m})$.

\subsection{Match to GICC05 during the Laschamp event}

The Laschamp geomagnetic excursion gives rise to a structured peak in the ${ }^{10} \mathrm{Be}$ records from Greenland (Yiou et al., 1997) and Antarctica (Raisbeck et al., 2002), which can be used to synchronise EDC96 to GRIP (Raisbeck et al., 2007), and in turn, to NGRIP dated by layer counting (GICC05, Andersen et al., 2006; Svensson et al., 2006). Two of the ${ }^{10} \mathrm{Be}$ sub-peaks have been localized in the EDC96 ice core at $735.35 \mathrm{~m}$ and $744.81 \mathrm{~m}$, and at $2231.9 \mathrm{~m}$ and $2246.2 \mathrm{~m}$ at GRIP. The corresponding GICC05 age for the middle of these two peaks is $41200 \mathrm{yr} \mathrm{BP}$ (max counting error of $1627 \mathrm{yr}$ ), corresponding to a depth of $740.08 \mathrm{~m}$ at EDC (Raisbeck et al., 2002) and we adopt this age. 
This age of the Laschamp event is compatible (within the uncertainties) with $\mathrm{K}-\mathrm{Ar}$ and ${ }^{40} \mathrm{Ar}-{ }^{39} \mathrm{Ar}$ ages from contemporaneous lava flow (40.4 $\pm 2.0 \mathrm{kyr}$ BP, Guillou et al., 2004). During this time period, which corresponds to D-O event 10 (Yiou et al., 1997; Raisbeck et al., 2002), GICC05 is also in good agreement with the Hulu Cave U-Th chronology (41.4 kyr BP, Wang et al., 2001), and with the Cariaco basin record (Hughen et al., 2004) when its ${ }^{14} \mathrm{C}$ ages are calibrated following the Fairbanks et al. (2005) curve (we obtain again an age of $41.2 \mathrm{kyr} \mathrm{BP}$ for the middle of the ${ }^{10} \mathrm{Be}$ peak corresponding to the middle of D-O 10). Genty et al. (2003) also found a compatible U-Th age of $40.0 \mathrm{kyr}$ BP for the middle of D-O 10, though the identification of D-O 10 in this record is more ambiguous.

\subsection{The Mont Berlin ash layer}

Thanks to geochemical data (major elements and trace elements), Narcisi et al. (2006) identified a volcanic ash layer originating from a Mt Berlin (Antarctica) eruption. This event has been dated at $92.5 \pm 2 \mathrm{kyr}$ BP by an $\mathrm{Ar} / \mathrm{Ar}$ method applied on ash material collected close to the volcano.

\subsection{Timing of termination II}

The age of the rapid $\mathrm{CH}_{4}$ event marking the end of termination II can be found by comparison to U-Th dated speleothem records, assuming that these fast transitions are synchronous. We obtain 129.3 kyr BP from Dongge cave in China (Yuan et al., 2004), and $130.9 \mathrm{kyr}$ BP from Pekiin cave in Northern Israel (Bar-Matthews et al., 2003). We took the average of these two ages (130.1 kyr BP) and assumed a confidence interval of $2 \mathrm{kyr}$. We used the $\Delta$ depth estimate from the EDC2 age scale to export the $\mathrm{CH}_{4}$ depth of $1723 \mathrm{~m}$ to an ice depth of $1699 \mathrm{~m}$ on EDC99. The uncertainty introduced by this ice/gas depth difference evaluation is only a few hundred years, so it is negligible compared to the uncertainty in the absolute age.

\subsection{Air content age markers $0-440 \mathrm{kyr} B \mathrm{~B}$}

The total air content of polar ice may be interpreted as a marker of the local summer insolation (Raynaud et al., 2007). Apparently, the solar radiative power absorbed at the surface influences the snow structure in the first upper meters and, in turn, the porosity of snow in the bubble close-off layer. The detailed physical mechanism is still under debate, however, the presence of a strong $41 \mathrm{kyr}$ obliquity period in the air content signal makes it appropriate for the application of an orbital tuning method. We used 19 age markers from the air content age scale available back to $440 \mathrm{kyr}$ BP. Each age marker corresponds to a minimum of obliquity, and the assumed uncertainty is $4 \mathrm{kyr}^{2}$.

\footnotetext{
${ }^{2}$ Since the definition of these air content age markers, the method to reconstruct a local insolation metronome based on the
}

\section{$2.8{ }^{18} \mathrm{O}_{\text {atm }}$ age markers for stages $300-800 \mathrm{kyr} \mathrm{BP}$}

A relationship between the isotopic composition of atmospheric oxygen $\left(\delta^{18} \mathrm{O}\right.$ of $\mathrm{O}_{2}$, noted $\left.\delta^{18} \mathrm{O}_{\text {atm }}\right)$ and daily northern hemisphere summer insolation has been observed at Vostok for the youngest four climate cycles. This property has been exploited to construct various orbital age scales for Vostok (Petit et al., 1999; Shackleton, 2000). Dreyfus et al. (2007) used a similar approach to derive an age scale for the bottom part of the EDC ice core (300-800 kyr BP) by assuming that ${ }^{18} \mathrm{O}_{\text {atm }}$ lags the summer-solstice precession variations by $5 \mathrm{kyr}$ with an estimated uncertainty of $6 \mathrm{kyr}$. The selected age markers are placed at each mid-transition of $\delta^{18} \mathrm{O}_{\mathrm{atm}}$ (see Dreyfus et al., 2007, for more details).

\subsection{The Brunhes-Matuyama reversal}

The most recent of the geomagnetic inversions, referred to as the Brunhes-Matuyama reversal, has been localized between 3161 and $3170 \mathrm{~m}$ in the EDC ${ }^{10} \mathrm{Be}$ record (Raisbeck et al., 2006). This reversal has been dated radiometrically to have occurred $776 \pm 12 \mathrm{kyr}$ BP (Coe et al., 2004), taking into account decay constant and calibration uncertainties. This transition has also been orbitally dated to be $778 \mathrm{kyr}$ ago (Tauxe et al., 1996). Several authors have also reported evidence for a "precursor" event, $15 \mathrm{kyr}$ before the B-M boundary (Brown et al., 2004), supported by the EDC ${ }^{10} \mathrm{Be}$ record.

\section{Construction of the time scale}

\subsection{The EDC3 age scale}

The EDC 3 age scale was constructed in three stages.

First, a preliminary dating was obtained by ice flow modelling alone (Parrenin et al., 2007). The ice flow model has two components. 1) The initial annual layer thickness (i.e. the accumulation rate) is evaluated from the deuterium content of the ice, assuming an exponential relationship between accumulation rate and deuterium content, the later being corrected for variations in isotopic composition of the mean ocean. 2) The vertical compression of the layers, or total thinning ratio, is evaluated with a mechanical model. The age at a depth $z$ is then given by:

age $(z)=\int_{0}^{z} \frac{1}{T\left(z^{\prime}\right) a\left(z^{\prime}\right)} d z^{\prime}$.

where $a(z)$ is the initial annual layer thickness and $\mathrm{T}(z)$ is the compression factor. This ice flow model contains several poorly known parameters: the average Holocene accumulation rate, the slope between deuterium and logarithm of accumulation, the basal melting, and two parameters for

EDC air content record has been improved and the final air content age scale is slightly different. 
the vertical profile of velocity (basal sliding and internal deformation). The values of these parameters have been determined by independent age markers, using a Monte Carlo Markov Chain (MCMC) inverse method. 21 age markers have been selected and are listed in Table 1. Not all those listed in Sect. 2 have been selected, in order to prevent overtuning the model in certain parts which would be a detriment to other parts. There are 8 age markers during the last climatic cycle, and in particular 3 during the Holocene. It is important to understand how this "modelled" age scale is dependent on these age markers. The average Holocene accumulation rate impacts the Holocene ages and is mainly constrained by the Holocene age markers (dated volcanoes and ${ }^{10} \mathrm{Be}$ age markers). Then the deuterium - accumulation slope affects the glacial ages and is mainly constrained by the age of the Laschamp event. The basal melting influences the total duration of the record and is mainly constrained by the bottom age markers. Finally, the two parameters related to the vertical profile of velocity only induce general trends in the age scale and are constrained by all the other age markers. Hence, the resulting age scale does not match perfectly the age markers obtained by comparison to insolation variations (obtained from the air content record).

The second stage is an a posteriori strict match of the age scale to dated volcanoes and to the NorthGRIP GICC05 time scale in the top part. In this part, the total thinning function is close to 1 and thought to be well constrained by the ice flow model. For this reason we expect the main sources of uncertainties to come from the accumulation model. Consequently we modified the modelled accumulation rate so that the resulting age scale fits perfectly with: 1) the dated volcanoes of the last millenium; 2) the two ${ }^{10} \mathrm{Be}$ age markers in the last $6 \mathrm{kyr}$ (Sect. 2.2); 3) one methane age marker during the last deglaciation (Sect. 2.3); 4) the Laschamp age marker at $41.2 \mathrm{kyr}$ BP (Sect. 2.4). These age markers are listed in Table 1.

The third stage is a correction of the modelled thinning function in the bottom $500 \mathrm{~m}$ of the core (beyond MIS11, $\sim 400 \mathrm{kyr} \mathrm{BP})$, where the ice flow model is unable to fit the $\delta^{18} \mathrm{O}_{\text {atm }}$ age markers (Dreyfus et al., 2007). This problem was first detected by Lisiecki and Raymo (2005), who suggested a problem in the accumulation estimate. However, Dreyfus et al. (2007) showed, by a comparison of deuterium and $\mathrm{CO}_{2}$ variations, that this anomaly is principally due to the presence of ice flow irregularities. They a posteriori corrected the total thinning function so that the resulting age scale fits those $\delta^{18} \mathrm{O}_{\text {atm }}$ age markers within their confidence interval. See Dreyfus et al. (2007, Table 1) for a complete list of the age markers used and for more details on the method.

By following this procedure, we have used the best available chronological information for each section of the core, while still allowing the model to provide a smooth interpolation of all unconstrained periods.

As stated in the introduction, two different cores have been drilled at EDC: EDC96 extending to $788 \mathrm{~m}$ depth (approxi-
Table 1. Age markers used for the construction of the EDC3 age scale. They fall into 3 categories: 1) Age markers used to control the poorly known parameters of the modelling; 2) Age markers used for a posteriori correction in the top part of the core (EDC3 is required to pass exactly through those age markers); 3) Age markers used to correct for ice flow anomalies in the bottom part.

\begin{tabular}{|c|c|c|c|c|c|c|}
\hline age marker & $\begin{array}{l}\text { depth } \\
\text { (m) }\end{array}$ & $\begin{array}{l}\text { age } \\
\text { (kyr BP) }\end{array}$ & $\begin{array}{l}\text { error bar } \\
\text { (kyr BP) }\end{array}$ & $\begin{array}{l}\text { model } \\
\text { control }\end{array}$ & $\begin{array}{l}\text { top } \\
\text { correction }\end{array}$ & $\begin{array}{l}\text { bottom } \\
\text { correction }\end{array}$ \\
\hline Krakatua & 8.35 & 0.066 & 0.001 & & $\mathrm{X}$ & \\
\hline Tambora & 12.34 & 0.134 & 0.001 & & $\mathrm{X}$ & \\
\hline Huaynaputina & 23.20 & 0.349 & 0.001 & & $\mathrm{X}$ & \\
\hline Kuwae & 29.27 & 0.492 & 0.005 & & $\mathrm{X}$ & \\
\hline El Chichon? & 38.12 & 0.691 & 0.005 & $\mathrm{X}$ & $\mathrm{X}$ & \\
\hline Unidentified & 39.22 & 0.722 & 0.006 & & $\mathrm{X}$ & \\
\hline Unknown & 41.52 & 0.779 & 0.006 & & $\mathrm{X}$ & \\
\hline${ }^{10} \mathrm{Be} /{ }^{14} \mathrm{C}$ & 107.83 & 2.716 & 0.05 & $\mathrm{X}$ & & \\
\hline${ }^{10} \mathrm{Be} /{ }^{14} \mathrm{C}$ & 181.12 & 5.28 & 0.05 & $\mathrm{X}$ & $\mathrm{X}$ & \\
\hline YD/Holocene & 361.5 & 11.65 & 0.18 & $\mathrm{X}$ & & \\
\hline $\mathrm{PB} / \mathrm{BO}$ & 427.2 & 15.0 & 0.24 & $\mathrm{X}$ & $\mathrm{X}$ & \\
\hline${ }^{10} \mathrm{Be}$ peak & 740.08 & 41.2 & 1 & $\mathrm{X}$ & $\mathrm{X}$ & \\
\hline Mt Berlin erupt. & 1265.10 & 92.5 & 2 & $\mathrm{X}$ & & \\
\hline term. II & 1698.91 & 130.1 & 2 & $\mathrm{X}$ & & \\
\hline air content & 1082.34 & 70.6 & 4 & $\mathrm{X}$ & & \\
\hline air content & 1484.59 & 109.4 & 4 & $\mathrm{X}$ & & \\
\hline air content & 1838.09 & 147.6 & 4 & $\mathrm{X}$ & & \\
\hline air content & 2019.73 & 185.3 & 4 & $\mathrm{X}$ & & \\
\hline air content & 2230.71 & 227.3 & 4 & $\mathrm{X}$ & & \\
\hline air content & 2387.95 & 270.4 & 4 & $\mathrm{X}$ & & \\
\hline air content & 2503.74 & 313.4 & 4 & $\mathrm{X}$ & & \\
\hline air content & 2620.23 & 352.4 & 4 & $\mathrm{X}$ & & \\
\hline air content & 2692.69 & 390.5 & 4 & $\mathrm{X}$ & & \\
\hline air content & 2789.58 & 431.4 & 4 & $\mathrm{X}$ & & \\
\hline${ }^{18} \mathrm{O}_{\mathrm{atm}}$ & 2714.32 & 398.4 & 6 & & & $\mathrm{X}$ \\
\hline${ }^{18} \mathrm{O}_{\mathrm{atm}}$ & 2749.04 & 408.6 & 6 & & & $\mathrm{X}$ \\
\hline${ }^{18} \mathrm{O}_{\mathrm{atm}}$ & 2772.27 & 422.0 & 6 & & & $\mathrm{X}$ \\
\hline${ }^{18} \mathrm{O}_{\mathrm{atm}}$ & 2799.36 & 441.0 & 6 & & & $\mathrm{X}$ \\
\hline${ }^{18} \mathrm{O}_{\mathrm{atm}}$ & 2812.69 & 454.3 & 6 & & & $\mathrm{X}$ \\
\hline${ }^{18} \mathrm{O}_{\mathrm{atm}}$ & 2819.2 & 464.6 & 6 & & & $\mathrm{X}$ \\
\hline${ }^{18} \mathrm{O}_{\mathrm{atm}}$ & 2829.36 & 474.8 & 6 & & & $\mathrm{X}$ \\
\hline${ }^{18} \mathrm{O}_{\mathrm{atm}}$ & 2841.75 & 485.3 & 6 & & & $\mathrm{X}$ \\
\hline${ }^{18} \mathrm{O}_{\mathrm{atm}}$ & 2856.27 & 495.9 & 6 & & & $\mathrm{X}$ \\
\hline${ }^{18} \mathrm{O}_{\mathrm{atm}}$ & 2872.56 & 506.6 & 6 & & & $X$ \\
\hline${ }^{18} \mathrm{O}_{\mathrm{atm}}$ & 2890.33 & 517.6 & 6 & & & $X$ \\
\hline${ }^{18} \mathrm{O}_{\mathrm{atm}}$ & 2913.3 & 532.0 & 6 & & & $\mathrm{X}$ \\
\hline${ }^{18} \mathrm{O}_{\mathrm{atm}}$ & 2921.99 & 545.3 & 6 & & & $\mathrm{X}$ \\
\hline${ }^{18} \mathrm{O}_{\mathrm{atm}}$ & 2938.24 & 556.4 & 6 & & & $\mathrm{X}$ \\
\hline${ }^{18} \mathrm{O}_{\mathrm{atm}}$ & 2968.08 & 567.6 & 6 & & & $\mathrm{X}$ \\
\hline${ }^{18} \mathrm{O}_{\mathrm{atm}}$ & 2998.96 & 578.6 & 6 & $\mathrm{X}$ & & $\mathrm{X}$ \\
\hline${ }^{18} \mathrm{O}_{\mathrm{atm}}$ & 3008.93 & 589.5 & 6 & & & $\mathrm{X}$ \\
\hline${ }^{18} \mathrm{O}_{\mathrm{atm}}$ & 3017.25 & 600.1 & 6 & & & $\mathrm{X}$ \\
\hline${ }^{18} \mathrm{O}_{\mathrm{atm}}$ & 3027.54 & 610.9 & 6 & & & $\mathrm{X}$ \\
\hline${ }^{18} \mathrm{O}_{\mathrm{atm}}$ & 3035.41 & 622.1 & 6 & $\mathrm{X}$ & & $\mathrm{X}$ \\
\hline${ }^{18} \mathrm{O}_{\mathrm{atm}}$ & 3043.01 & 634.4 & 6 & & & $\mathrm{X}$ \\
\hline${ }^{18} \mathrm{O}_{\mathrm{atm}}$ & 3048.51 & 649.1 & 6 & & & $\mathrm{X}$ \\
\hline${ }^{18} \mathrm{O}_{\mathrm{atm}}$ & 3056.77 & 660.8 & 6 & & & $\mathrm{X}$ \\
\hline${ }^{18} \mathrm{O}_{\mathrm{atm}}$ & 3065.93 & 671.7 & 6 & & & $\mathrm{X}$ \\
\hline${ }^{18} \mathrm{O}_{\mathrm{atm}}$ & 3077.74 & 682.3 & 6 & & & $\mathrm{X}$ \\
\hline${ }^{18} \mathrm{O}_{\mathrm{atm}}$ & 3093.51 & 693.2 & 6 & & & $\mathrm{X}$ \\
\hline${ }^{18} \mathrm{O}_{\mathrm{atm}}$ & 3112.43 & 704.0 & 6 & & & $\mathrm{X}$ \\
\hline${ }^{18} \mathrm{O}_{\mathrm{atm}}$ & 3119.57 & 714.4 & 6 & & & $\mathrm{X}$ \\
\hline${ }^{18} \mathrm{O}_{\mathrm{atm}}$ & 3124.27 & 724.4 & 6 & & & $\mathrm{X}$ \\
\hline${ }^{18} \mathrm{O}_{\mathrm{atm}}$ & 3136.18 & 733.9 & 6 & & & $\mathrm{X}$ \\
\hline${ }^{18} \mathrm{O}_{\mathrm{atm}}$ & 3143.2 & 741.9 & 6 & & & $\mathrm{X}$ \\
\hline${ }^{18} \mathrm{O}_{\mathrm{atm}}$ & 3152.25 & 749.2 & 6 & & & $\mathrm{X}$ \\
\hline${ }^{18} \mathrm{O}_{\mathrm{atm}}$ & 3158.91 & 758.1 & 6 & & & $\mathrm{X}$ \\
\hline${ }^{18} \mathrm{O}_{\mathrm{atm}}$ & 3166.87 & 767.7 & 6 & & & $\mathrm{X}$ \\
\hline${ }^{18} \mathrm{O}_{\mathrm{atm}}$ & 3174.81 & 777.6 & 6 & & & $\mathrm{X}$ \\
\hline${ }^{18} \mathrm{O}_{\mathrm{atm}}$ & 3180.6 & 787.7 & 6 & & & $\mathrm{X}$ \\
\hline${ }^{18} \mathrm{O}_{\mathrm{atm}}$ & 3189.83 & 797.5 & 6 & & & $\mathrm{X}$ \\
\hline B-M reversal & 3165 & 785 & 20 & $\mathrm{X}$ & & \\
\hline
\end{tabular}




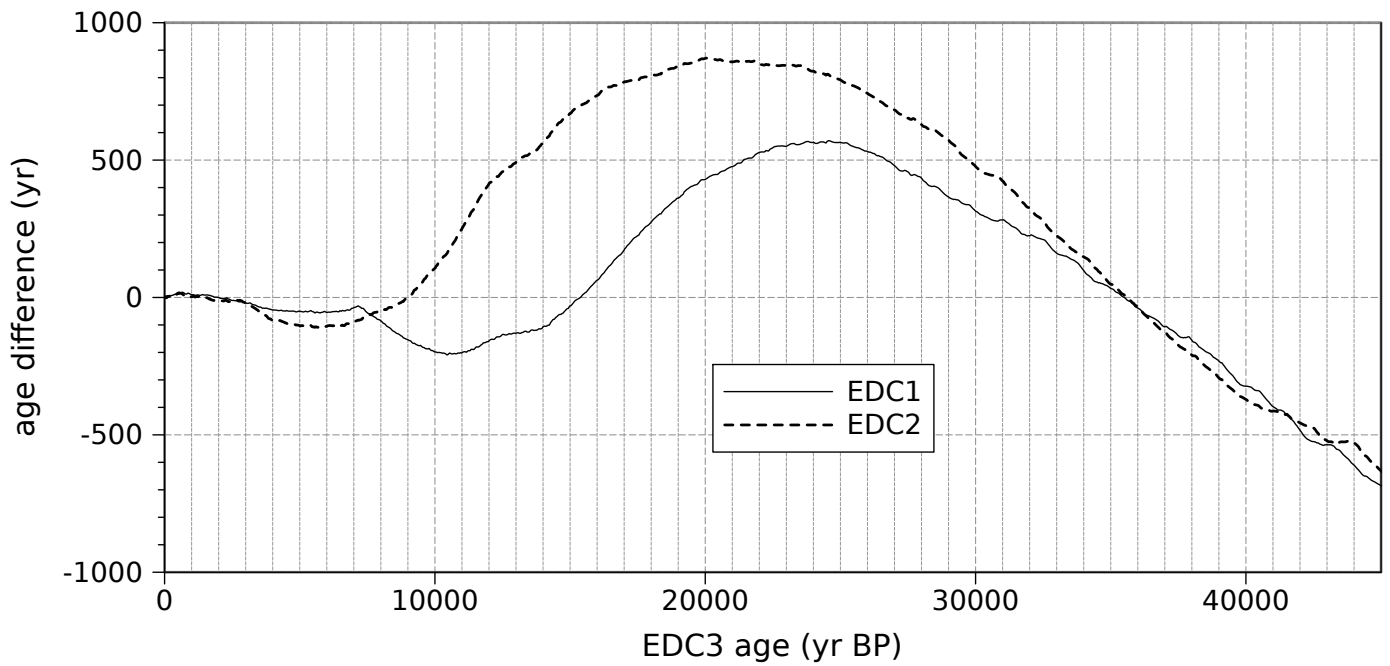

Fig. 1. Age difference between the EDC1 (resp. EDC2) and EDC3 time scales for the last $45 \mathrm{kyr}$.

mately back to $45 \mathrm{kyr}$ BP), and EDC99 drilled down to the bedrock. For the first $\sim 45 \mathrm{kyr}$, the majority of paleoclimatic reconstructions have been obtained from EDC96. Therefore, EDC 3 has been defined on EDC96 depths on the shallow part and on EDC99 depths in the bottom part. The age scale has then been transferred to EDC99 in the shallow part thanks to a volcanic synchronisation of the two cores (Wolff et al., 2005).

Estimates of the gas-ice age difference and related discussions can be found in Loulergue et al. (2007).

\subsection{EDC3 exported to EDML, Dome Fuji and Vostok}

The EDC3 age scale was then exported to EDML, Dome Fuji and Vostok thanks to synchronisation of these ice cores with EDC. The EDC-EDML synchronisation and the resulting EDML1 chronology are fully described in Severi et al. (2007) and Ruth et al. (2007). The EDC-DF and EDCVK synchronisations are done by matching isotopic records, and by using common volcanic horizons (Narcisi et al., $2005^{3}$ ). See supplementary material (http://www.clim-past. net/3/485/2007/cp-3-485-2007-supplement.zip) for a list of synchronisation markers used.

\section{EDC3 compared to other age scales}

\subsection{Comparison with EDC1 and EDC2}

The former EDC1 time scale for EDC96 (Schwander et al., 2001), and the extended EDC2 for the last $740 \mathrm{kyr}$ (EPICA

\footnotetext{
${ }^{3}$ We did not use the EDC-VK volcanic synchronisation obtained by Udisti et al. (2004), because it concerns the 5G VK core, and not the $3 \mathrm{G}$ core on which the deuterium measurements have been performed.
}

community members, 2004) were also built on a combination of age markers and modelling information. As for EDC3, a one dimensional ice flow model was controlled by a set of age markers. There are however several important differences. For EDC1, the time scale extended only back to $45 \mathrm{kyr}$ BP, and different glaciological parameters were used for different time periods covered by the time scale. EDC2 extended only back to $740 \mathrm{kyr}$ BP and there was no a posteriori correction of the age scale, neither in the top part, nor in the bottom part where the ice flow is complex. Moreover, the ice flow model did not take into account basal sliding and variations in ice sheet thickness, and the age markers were mainly obtained by comparison to the oceanic Bassinot stack (Bassinot et al., 1994).

Figure 1 compares EDC1 and EDC3 on the last $45 \mathrm{kyr}$. EDC2 is also shown for convenience, but EDC1 was still the official age scale for the top part of the core. EDC3 is younger by a few decades for the last $2 \mathrm{kyr}$. Then it is older by less than $100 \mathrm{yr}$ between 2 and $8 \mathrm{kyr}$ BP. The difference increases to $\sim 200 \mathrm{yr}$ for the early Holocene period, around $10 \mathrm{kyr}$ BP. Then the difference becomes positive (EDC1 is older) with a maximum of $\sim 600 \mathrm{yr}$ at the LGM. The difference finally decreases roughly linearly down to $-700 \mathrm{yr}$ at 45 kyr BP.

Figure 2 compares EDC2 and EDC3. The difference ranges approximately between -1.5 and $+3 \mathrm{kyr}$ for the last $400 \mathrm{kyr}$. EDC3 is older during the last glacial period, with a difference of $\sim 3 \mathrm{kyr}$ for MIS 5.5. This is due in particular to the use of the Mt Berlin and Termination II age markers. The difference between EDC3 and EDC2 then slowly decreases back to MIS 10.

For the period $400-800 \mathrm{kyr}$ BP, the difference is much larger, and reaches -20 and $+7 \mathrm{kyr}$. This is due to the a posteriori correction in EDC3 of ice flow irregularities in the bottom part of the core. The largest differences are for MIS 


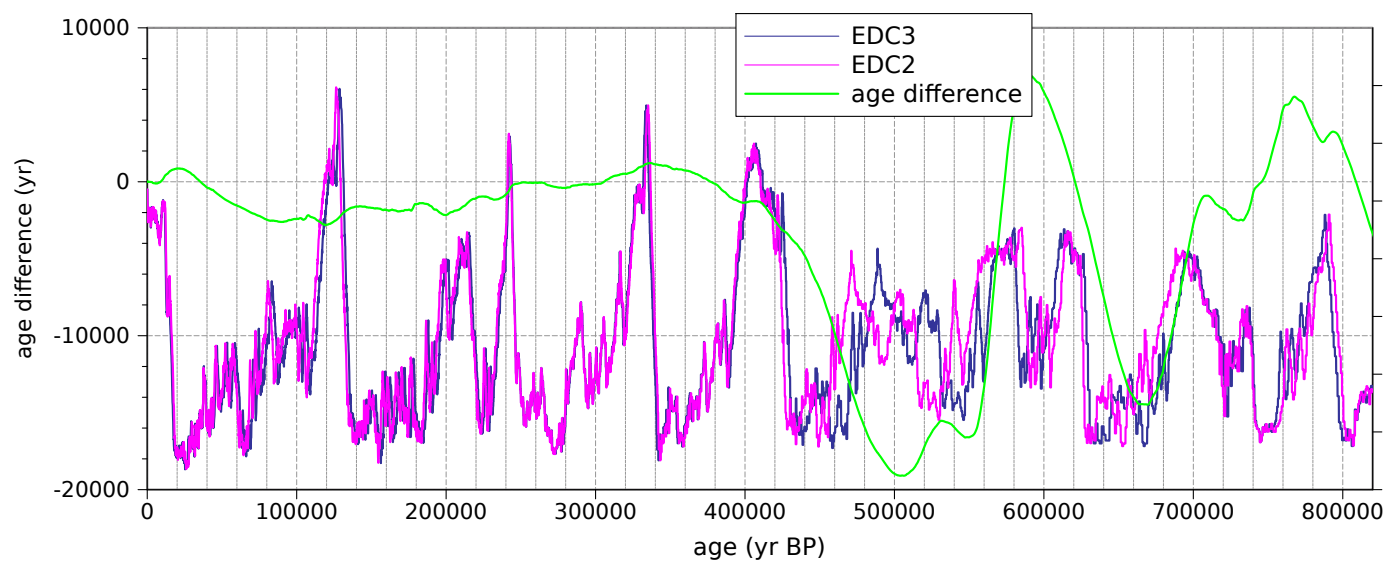

Fig. 2. Comparison of the EDC deuterium record on the EDC 2 and EDC3 time scales. The green curve represents the difference in age between EDC2 and EDC3. Y-axes for isotopic records are normalised.

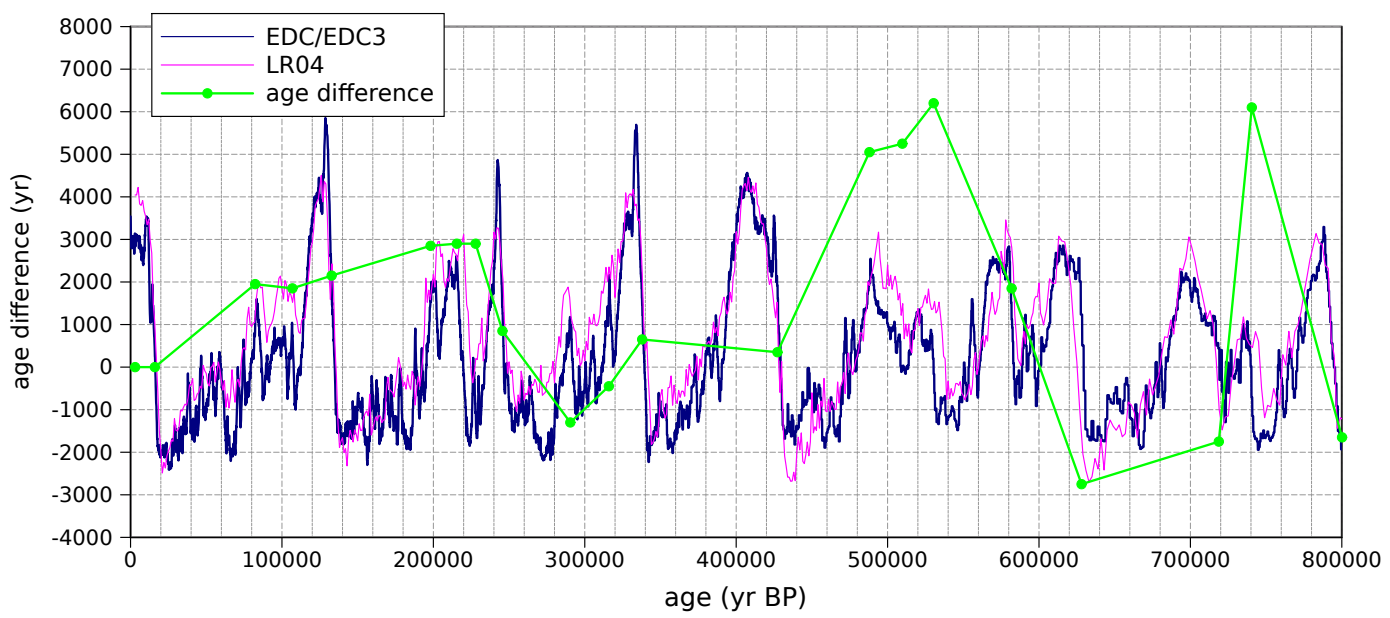

Fig. 3. Comparison of the EDC deuterium record on the EDC 3 time scale with the LR04 marine stack on its own time scale, shifted by 3 kyr towards older ages. The green curve represents the difference in age between LR04 (+3 kyr) and EDC 3 assuming both records are synchronous. Y-axes for isotopic records are normalised.

13-14 (where EDC3 is older by 15-20 kyr), MIS 15.3 (where EDC3 is younger by $\sim 5 \mathrm{kyr}$ ) and MIS 16 (where EDC3 is older by 10-15 kyr). Duration of MIS 15.1 has been considerably shortened in EDC3, while the duration of MIS 12 is now longer.

\subsection{Comparison with LR04}

The LR04 marine stack is composed of benthic $\delta^{18} \mathrm{O}$ records from 57 globally distributed sites aligned by an automated graphic correlation algorithm (Lisiecki and Raymo, 2005). The LR04 age model is derived from tuning the $\delta^{18} \mathrm{O}$ stack to a simple ice model based on 21 June insolation at $65^{\circ} \mathrm{N}$, with additional constraints from the sedimentation to prevent overtuning.

In Fig. 3, we compared the EDC deuterium record on EDC3 with the LR04 stack on its own time scale. Of course, as a benthic record, LR04 contains a sea level part and a temperature part and as a consequence is older than EDC by several thousands of years. For an easier comparison, we thus shifted it by $3 \mathrm{kyr}$ towards older ages. This $3 \mathrm{kyr}$ phase is the observed phase of both records during the last deglaciation. On Fig. 3 is also plotted the age difference between the two age scales (with the $3 \mathrm{kyr}$ phase lag removed). For that, we used features that can be identified with confidence in both curves (e.g. terminations). We preferentially placed points at mid-transitions.

The overall agreement between both time scales is good, with differences never exceeding $6 \mathrm{kyr}$. In contrast, the previous EDC2 time scale showed disagreements up to $20 \mathrm{kyr}$ with LR04 in the part older than $400 \mathrm{kyr}$ BP (Lisiecki and Raymo, 2005; Dreyfus et al., 2007). The age difference is particularly small during the last $400 \mathrm{kyr}$ (back to MIS11), 


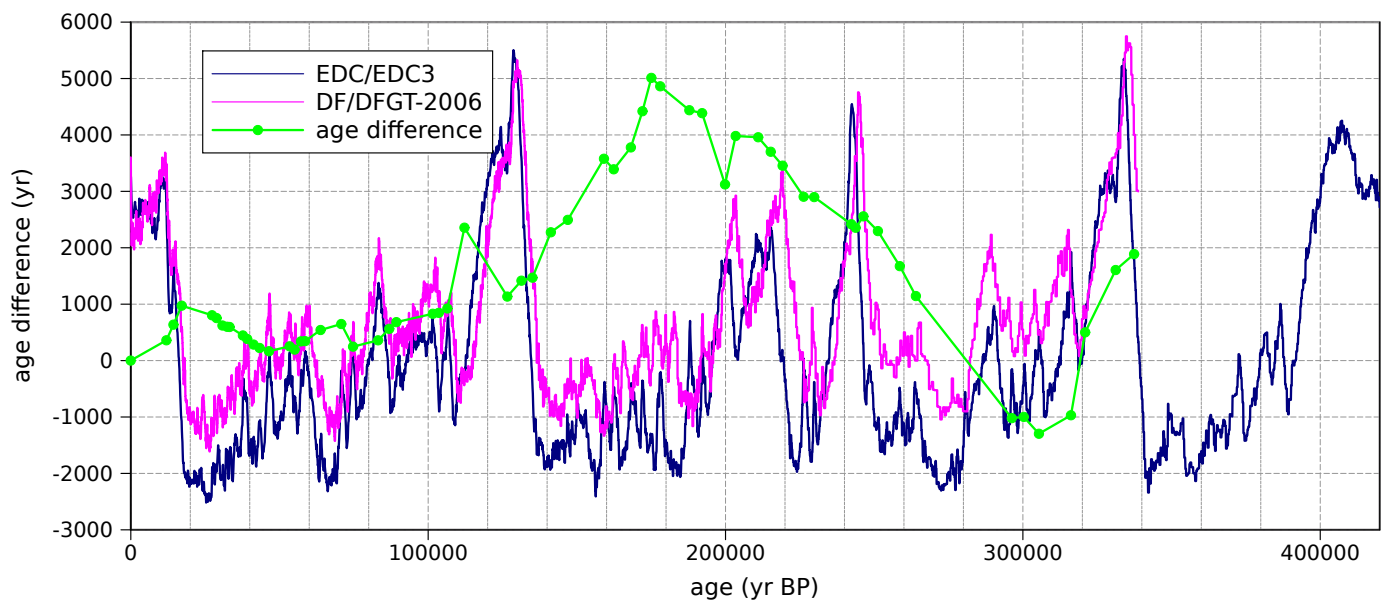

Fig. 4. Comparison of the EDC deuterium record on the EDC 3 time scale with the Dome Fuji $\delta^{18}$ O record on the DFGT-2006 time scale (Parrenin et al., 2007). The green curve represents the difference in age between DFGT-2006 and EDC3 at the depth of the synchronisation markers. Y-axes for isotopic records are normalised.

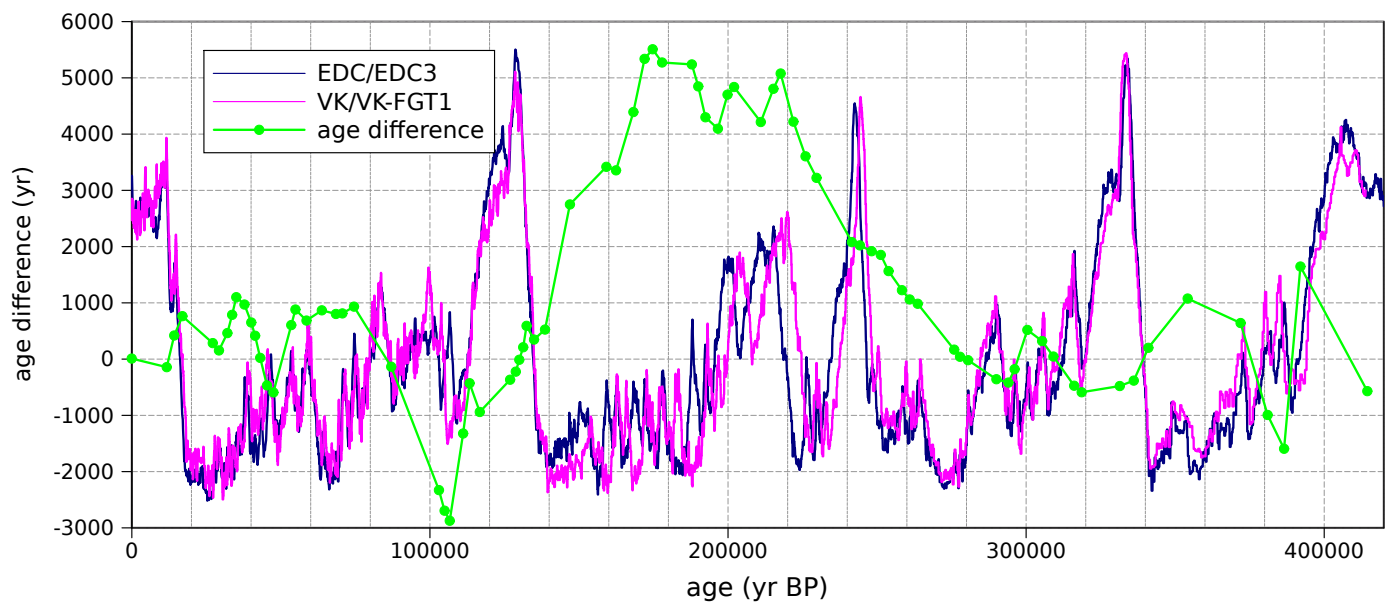

Fig. 5. Comparison of the EDC deuterium record on the EDC3 time scale with the Vostok deuterium record on the VK-FGT1 time scale (Parrenin et al., 2004). The green curve represents the difference in age between VK-FGT1 and EDC3 at the depth of the synchronisation markers. Y-axes for isotopic records are normalised.

oscillating between $-1.5 \mathrm{kyr}$ and $3 \mathrm{kyr}$. This age difference may reflect either errors in the synchronisation, or may be due to phases in the climatic system, i.e. related to the fact that both curves do not represent the same climatic proxy. The fact that this difference is stable is reassuring because it shows a certain consistency between both time scales which were derived completely independently. The glaciological modelling method thus seems appropriate for Dome $\mathrm{C}$ back to MIS11 without any additional distortion. The age difference increases to approximately $6 \mathrm{kyr}$ between 450 and $600 \mathrm{kyr} \mathrm{BP}$, then reaches its minimum at termination VII (from MIS16 to MIS15) with $-3 \mathrm{kyr}$, increases again to $6 \mathrm{kyr}$ at MIS18, and finally decreases to around $-2 \mathrm{kyr}$ at termination 9 (from MIS20 to MIS19). This bottom interval (beyond MIS11) where the age difference is less stable, is where the ice flow model becomes inaccurate (Dreyfus et al., 2007).
4.3 Comparison with DF and VK glaciological chronologies

In Fig. 4 and Fig. 5, we compare the EDC isotopic record on the EDC3 time scale with the Dome Fuji and Vostok isotopic record, on their respective glaciological age scales DFGT2006 (Parrenin et al., 2007) and VK-FGT1 (Parrenin et al., 2004).

The age differences are always less than $1 \mathrm{kyr}$ for the last $\sim 90 \mathrm{kyr}$. This good agreement is especially remarkable because very few age markers were used for the last glacial part. We interpret it as the fact that the glaciological models used are robust for the upper part of the ice sheets where the mechanical ice flow is still predictable. It is also a proof that the assumed relationship between isotopic content of the ice and surface accumulation rate is valid within a few percent. 


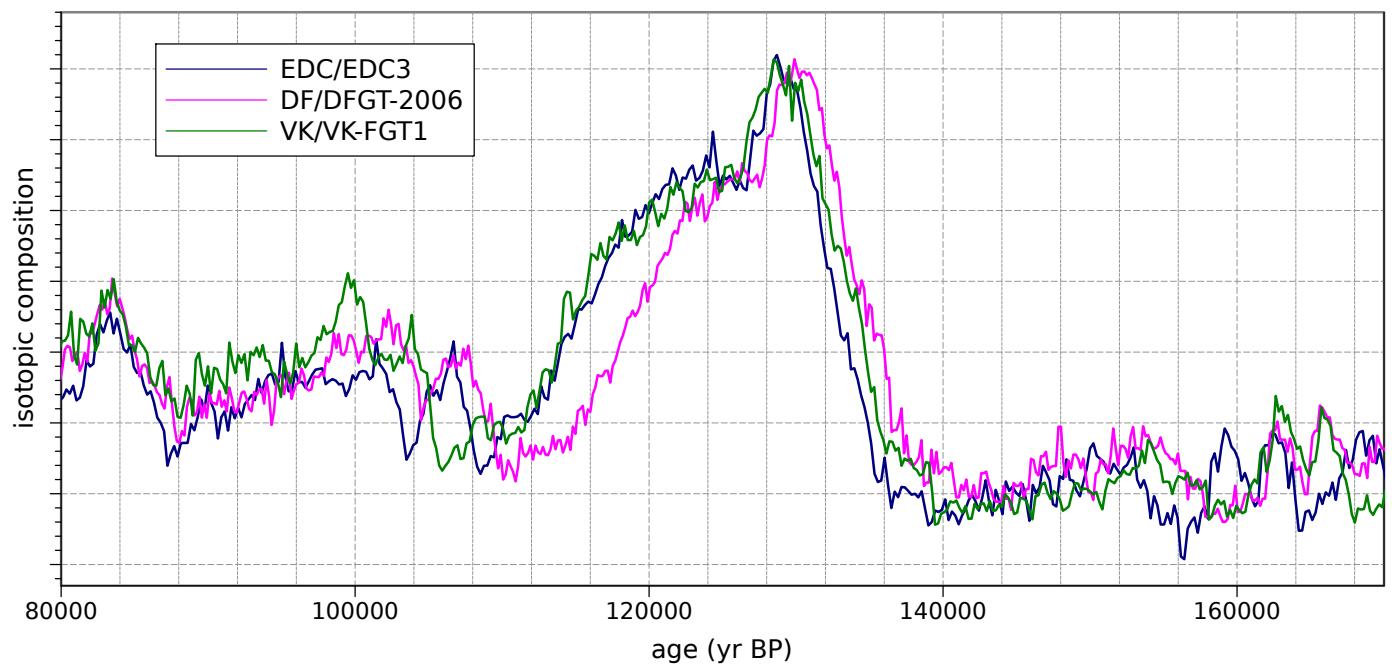

Fig. 6. Comparison of three glaciological age scales during the time interval MIS6-MIS5.4. The EDC deuterium record is on the EDC3 time scale. The Vostok deuterium record is on the VK-FGT1 time scale (Parrenin et al., 2004). The Dome Fuji $\delta^{18} \mathrm{O}$ record is on the DFGT-2006 time scale (Parrenin et al., 2007). Y-axes for isotopic records are normalised.

The age of term. II is roughly consistent in all three glaciological chronologies, as can be seen in Fig. 6. Using the rapid methane event marking the end of the deglaciation and corresponding to the end of the Antarctic isotope increase, we obtain $129.2 \mathrm{kyr}$ BP in EDC3, $129 \mathrm{kyr}$ BP in VK-FGT1 and $129.8 \mathrm{kyr}$ BP in DFGT-2006. This age is also in good agreement with estimates based on coral-reef high stands (Waelbroeck et al., 20074). The age old debate on the age of Termination II, old in a previous ice core chronology (Lorius et al., 1985) and young in the orbitally tuned marine records (Imbrie et al., 1984) now seems to be converging.

The age discrepancies are larger for the second climatic cycle, where EDC3 is significantly older than both DFGT2006 and VK-FGT1, the difference reaching around $5 \mathrm{kyr}$. The agreement is again better for the third and fourth climatic cycles, with differences never exceeding $2 \mathrm{kyr}$.

Figure 7 compares the duration of climatic events in EDC3 and DFGT-2006, or in EDC3 and VK-FGT1. These three time scales are consistent, generally within $20 \%$. It should be noted that differences depicted on this figure may either reflect a real difference in the age scales, or an error in the synchronisation process. The agreement is very good back to $\sim 90 \mathrm{kyr} \mathrm{BP}$, but then the situation for MIS5.4 to 6 is more complex (see Fig. 6). MIS5.4 is significantly shorter in EDC3 than in DFGT-2006 and VK-FGT1. Then, the duration of MIS5.5 ( $\sim 16 \mathrm{kyr}$, taken at mid-transitions) is intermediate in EDC3 between its duration in DFGT-2006 $(\sim 14.5 \mathrm{kyr})$ and its duration in VK-FGT1 $(\sim 18 \mathrm{kyr})$. Finally,

\footnotetext{
${ }^{4}$ Waelbroeck, C., Frank, N., Jouzel, J., Parrenin, F., MassonDelmotte, V., and Genty, D.: Transferring radiometric dating of the Last Interglacial sea level high stand to marine and ice core records, submitted, 2007.
}

the duration of MIS6 is significantly shorter in EDC3 than in both other age scales. We do not know at this stage if these discrepancies are due to poorly understood processes in the accumulation models or in the mechanical thinning models. A recent study on the structure of cristallographic orientations suggests non-unidimensional flow processes for this time period (Durand et al., 2007), and the authors suggest accurately monitoring the EDC borehole to quantify the amount of shear. A precise synchronisation between the ice cores in both the ice and gas phases may also help distinguish an accumulation anomaly from a thinning anomaly.

\section{Confidence interval of the age scale}

The confidence interval determination is a difficult task when no robust statistical information is available. Here, we evaluate it subjectively by using the comparison with the other age scales and with the age markers.

Back to AD1600, the error in EDC3 mainly comes from the interpolation of the dated volcanoes which we estimate it to be $3 \mathrm{yr}(2 \sigma)$. Between AD1100-1600, the age error of the volcanoes increases to $5 \mathrm{yr}$, and adding an interpolation error we estimate the total error at $8 \mathrm{yr}$. The accuracy is then constrained by the accuracy of the ${ }^{10} \mathrm{Be}$ age markers, which we estimate at $100 \mathrm{yr}$. We thus estimate that the $2 \sigma$ error on EDC3 increases to $100 \mathrm{yr}$ at $2000 \mathrm{yr}$ BP and stays stable back to $6000 \mathrm{yr} \mathrm{BP}$. The accuracy of EDC3 then increases to $400 \mathrm{yr}$ at $14 \mathrm{kyr} \mathrm{BP}$, which is roughly the error on the $\mathrm{CH}_{4}$ age markers. By comparison to the Dome Fuji and Vostok chronologies and to the GICC05 age of the Laschamp, we estimate the confidence interval to increase to $1 \mathrm{kyr}$ at $18 \mathrm{kyr}$ (Last Glacial Maximum), $1.5 \mathrm{kyr}$ at $40 \mathrm{kyr}$, and finally 

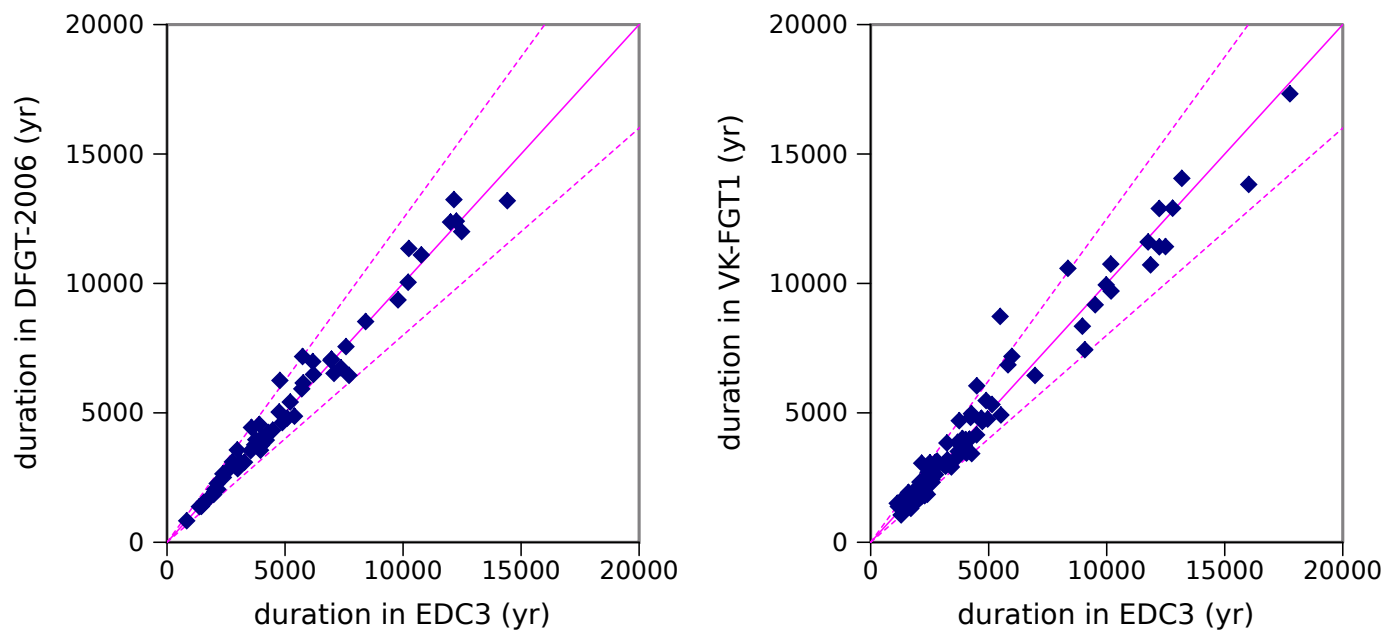

Fig. 7. Durations between two consecutive synchronisation markers in EDC3 compared to durations in DFGT-2006 (left panel) or in VKFGT1 (right panel). Plain pink line is the 1:1 curve. Dashed pink lines represent the 1:0.8 and 0.8:1 lines.

$3 \mathrm{kyr}$ at $100 \mathrm{kyr}$ BP. Our estimated confidence interval is constrained by the quality of the orbital tuning age markers from air content or ${ }^{18} \mathrm{O}_{\text {atm }}$ records; we estimate it to increase to $6 \mathrm{kyr}$ at $130 \mathrm{kyr}$ and to stay stable down to the bottom of the record.

In terms of event durations, we estimate the accuracy to be $20 \%$ for the top part of the record (back to MIS11), by comparison to Vostok and Dome Fuji glaciological age scales. For the bottom part (below MIS11), a more conservative estimate of $40 \%$ is more appropriate because of the flow anomalies (Dreyfus et al., 2007).

\section{Conclusion and perspectives}

We derived an EDC3 chronology for the EPICA Dome C ice core, which was then exported to EDML, Dome Fuji and Vostok ice cores by synchronisation of these ice cores. This chronology has been obtained using a combination of age markers and ice flow modelling. The good agreement between EDC, Vostok and Dome Fuji ice flow models points to the good accuracy of EDC3 in terms of event durations, which we estimate to be better than $20 \%$ for the last $400 \mathrm{kyr}$. This is a significant improvement with respect to marine age scales where the resolution is poorer and where the sedimentation is less regular.

Apart from ice flow modelling improvements, further developments need to be done concerning the inverse method used for the conjunction of models and age markers. The method used for EDC3 is based on a so-called deterministic approach, where the uncertainties in the ice flow models are supposed to originate from poorly known physical parameters. In reality, there are other non-identified sources of uncertainty in these models which need to be taken into account in a statistical way. A second potential improvement is to apply this inverse method to several drilling sites simultaneously, to obtain a common and optimal age scale for several ice cores, as has been done in the marine world (Lisiecki and Raymo, 2005).

We also hope that the precision of the age markers will increase in the coming years. The number of U-Th dated speleothems for the last climatic cycles should increase in the future (Henderson, 2006). New local insolation proxies such as $\mathrm{O}_{2} / \mathrm{N}_{2}$ and air content are also a promising source of accurate age markers, but the physical mechanisms involved need to be better understood and the accuracy of these age scales needs to be independently confirmed.

Acknowledgements. We thank the logistics and drilling teams, responsible for the recovery of the EDC and EDML ice cores. This work is a contribution to the European Project for Ice Coring in Antarctica (EPICA), a joint European Science Foundation/European Commission scientific programme, funded by the EU (EPICA-MIS) and by national contributions from Belgium, Denmark, France, Germany, Italy, the Netherlands, Norway, Sweden, Switzerland and the United Kingdom. The main logistic support was provided by IPEV and PNRA (at Dome C) and AWI (at Dronning Maud Land). It was partly funded by the French ANR projects MIDIGA and PICC. This is EPICA publication no. 184.

Edited by: E. Brook

\section{References}

Alley, R. B., Shuman, C. A., Meese, D. A., Gow, A. J., Taylor, K. C., Cuffey, K. M., Fitzpatrick, J. J., Grootes, P. M., Zielinski, G. A., Ram, M., Spinelli, G., and Elder, B.: Visual-stratigraphic dating of the GISP2 ice core: Basis, reproductibility, and application, J. Geophys. Res., 102(C12), 26367-26381, 1997.

Andersen, K. K., Svensson, A., Johnsen, S. J., Rasmussen, S. O., Bigler, M., Röthlisberger, R., Ruth, U., Siggaard-Andersen, 
M.-L., Steffensen, J. P., Dahl-Jensen, D., Vinther, B. M., and Clausen, H. B.: The Greenland Ice Core Chronology 2005, 1542 kyr. Part 1: Constructing the time scale, Quat. Sci. Rev., 25, 3246-3257, 2006.

Bar-Matthews, M., Ayalon, A., Gilmour, M., Matthews, A., and Hawkesworth, C. J.: Sea-land oxygen isotopic relationships from planktonic foraminifera and speleothems in the Eastern Mediterranean region and their implication for paleorainfall during interglacial intervals, Chem. Geol., 67, 3181-3199, 2003.

Bassinot, F. C., Labeyrie, L. D., Vincent, E., Quidelleur, X., Shackleton, N. J., and Lancelot, Y.: The astronomical theory of climate and the age of the Brunhes-Matuyama magnetic reversal, Earth Planet. Sci. Lett., 126(1-3), 91-108, 1994.

Bender, M. L: Orbital tuning chronology for the Vostok climate record supported by trapped gas composition, Earth Planet. Sci. Lett., 204, 275-289, 2002.

Bender, M., Sowers, T., Dickson, M., Orchado, J., Grootes, P., Mayewski, P., and Meese, D.: Climate connection between Greenland and Antarctica during the last 100,000 years, Nature, 372, 663-666, 1994.

Björck, S., Walker, M. J., Cwynar, L. C., Johnsen, S., Knudsen, K.-L., Lowe, J. J., Wohlfarth, B., and intimate members: An event stratigraphy for the Last Termination in the North Atlantic region based on the Greenland ice-core record: A proposal by the INTIMATE group, J. Quat. Sci., 13(4), 283-292, 1998.

Blunier, T., Chappellaz, J., Schwander, J., Dällenbach, A., Stauffer, B., Stocker, T., Raynaud, D., Jouzel, J., Clausen, H., Hammer, C., and Johnsen, S.: Asynchrony of Antarctic and Greenland climate change during the last glacial period, Nature, 394(6695), 739-743, 1998.

Brown, L. L., Singer, B. S., Pickens, J. C., and Jicha, B. R.: Paleomagnetic directions and ${ }^{40} \mathrm{Ar} /{ }^{39} \mathrm{Ar}$ ages from the TataraSan Pedro volcanic complex, Chilean Andes: Lava record of a Matuyama-Brunhes precursor?, J. Geophys. Res., 109(B12), B12101, doi:10.1029/2004JB003007, 2004.

Castellano, E., Becagli, S., Hansson, M., Hutterli, M., Petit, J. R., Rampino, M. R., Severi, M., Steffensen, J. P., Traversi, R., and Udisti, R.: Holocene volcanic history as recorded in the sulfate stratigraphy of the European Project for Ice Coring in Antarctica Dome C (EDC96) ice core, J. Geophys. Res., 116, D06114, doi:10.1029/2004JD005259, 2005.

Coe, R. S., Singer, B. S., Pringle, M. S., and Zhao, X.: MatuyamaBrunhes reversal and Kamikatsura event on Maui: paleomagnetic directions, ${ }^{40} \mathrm{Ar} /{ }^{39} \mathrm{Ar}$ ages and implications, Earth Planet. Sci. Lett., 222, 667-684, 2004.

Dansgaard, W. and Johnsen, S. J.: A flow model and a time scale for the ice core from Camp Century, Greenland, J. Glaciol., 8(53), 215-223, 1969.

Dansgaard, W., Clausen, H., Gundestrup, N., Johnsen, S., and Rygner, C.: Dating and climatic interpretation of two deep Greenland ice cores, in: Greenland Ice Core: Geophysics, Geochemistry, and the Environment, edited by: Langway, C. C. J., American Geophysical Union, Washington D.C., 1985.

Dreyfus, G. B., Parrenin, F., Lemieux-Dudon, B., et al.: Anomalous flow below $2700 \mathrm{~m}$ in the EPICA Dome $\mathrm{C}$ ice core detected using $\delta^{18} \mathrm{O}$ of atmospheric oxygen measurements, Clim. Past, 3, 341353,2007 ,

http://www.clim-past.net/3/341/2007/.

Durand, G., Gillet-Chaulet, F., Svensson, A., Gagliardini, O., Kipf- stuhl, S., Meyssonnier, J., Parrenin, F., Duval, P., and DahlJensen, D.: Change of the ice rheology with climatic transitions - implication on ice flow modelling and dating of the EPICA Dome C core, Clim. Past, 3, 155-167, 2007.

Ekaykin, A. A., Lipenkov, V. Y., Barkov, N. I., Petit, J.-R., and Masson-Delmotte, V.: Spatial and temporal variability in isotope composition of recent snow in the vicinity of Vostok station, Antarctica: implications for ice-core record interpretation, Ann. Glaciol., 35, 181-186, 2002.

EPICA community members: One-to-one coupling of glacial climate variability in Greenland and Antarctica, Nature, 444, 195198, 2006.

EPICA community members: 8 glacial cycles from an Antarctic ice core, Nature, 429, 623-628, 2004.

Fairbanks, R. G., Mortlock, R. A., Chiu, T.-C., Cao, L., Kaplan, A., Guilderson, T. P., Fairbanks, T. W., Bloom, A. L., Grootes, P. M., and Nadeau, M.-J.: Radiocarbon calibration curve spanning 0 to 50000 years BP based on paired ${ }^{230} \mathrm{Th} /{ }^{234} \mathrm{U} /{ }^{238} \mathrm{U}$ and ${ }^{14} \mathrm{C}$ dates on pristine corals, Quat. Sci. Rev., 24, 1781-1796, 2005.

Genty, D., Blamart, D., Ouhadi, R., Gilmour, M., Baker, A., Jouzel, J., and Van-Exter, S.: Precise dating of Dansgaard-Oeschger climate oscillations in western Europe from stalagmite data, Nature, 421, 833-837, 2003.

Goujon, C., Barnola, J.-M., and Ritz, C.: Modeling the densification of polar firn including heat diffusion: application to close-off characteristics and gas isotopic fractionation for Antarctica and Greenland sites, J. Geophys. Res., 108(D24), ACL10/1-10, 2003.

Guillou, H., Singer, B. S., Laj, C., Kissel, C., Scaillet, S., and Jicha, B. R.: On the age of the Laschamp geomagnetic excursion, Earth Planet. Sci. Lett., 227, 331-343, 2004.

Hammer, C. U., Clausen, H. B., and Langway, C. C.: Electrical conductivity method (ECM) stratigraphic dating of the Byrd Station ice core, Antarctica, Ann. Glaciol., 20, 115-120, 1994.

Henderson, G. M.: Caving In to New Chronologies, Science, 313, 620-622, 2006.

Henderson, G. M. and Slowey, N. C: Evidence from U-Th dating against northern hemisphere forcing of the penultimate deglaciation, Nature, 404(6773), 61-66, 2000.

Hughen, K., Lehman, S., Southon, J., Overpeck, J., Marchal, O., Herring, C. and Turnbull, J.: ${ }^{14} \mathrm{C}$ activity and global carbon cycle changes over the past 50000 years, Science, 303, 202-205, 2004

Huybrechts, P., Rybak, O., Pattyn, F., Ruth, U., and Steinhage, D.: Ice thinning, upstream advection, and non-climatic biases for the upper $89 \%$ of the EDML ice core from a nested model of the Antarctic ice sheet, Clim. Past Discuss., 3, 693-727, 2007, http://www.clim-past-discuss.net/3/693/2007/.

Imbrie, J., Hays, J. D., Martinson, D. G., McIntyre, A., Mix, A. C., Morley, J. J., Pisias, N. G., Prell, W. L., and Shackleton, N. J.: The orbital theory of Pleistocene climate: support from a revised chronology of the marine $\mathrm{d} 18 \mathrm{O}$ record, in: Milankovitch and climate, part 1, edited by: Berger, A., Imbrie, J., Hays, J., Kukla, G., and Saltzman, B., D. Riedel, Hingham, MA, 1984.

Johnsen, S. J. and Dansgaard, W.: On flow model dating of stable isotope records from Greenland ice cores, in: The Last Deglaciation: Absolute and Radiocarbon Chronologies, edited by: Bard, E. and Broecker, W. S., Springler Verlag, Berlin Heidelberg, 1992.

Johnsen, S., Dansgaard, W., Clausen, H., and Langway, C. J.: Oxygen isotope profiles through the Antarctic and Greenland ice 
sheets, Nature, 235(5339), 429-434, 1972.

Johnsen, S., Dahl-Jensen, D., Gundestrup, N., Steffensen, J., Clausen, H., Miller, H., Masson-Delmotte, V., Sveinbjornsdottir, A., and White, J.: Oxygen isotope and palaeotemperature records from six Greenland ice-core stations: Camp Century, Dye-3, GRIP, GISP2, Renland and NorthGRIP, J. Quat. Sci., 16, 299-307, 2001.

Jouzel, J., Vaikmae, R., Petit, J., Martin, M., Duclos, Y., Stievenard, M., Lorius, C., Toots, M., Mélières, M., Burckle, L., Barkov, N., and Kotlyakov, V.: The two-step shape and timing of the last deglaciation in antarctica, Clim. Dyn., 11, 151-161, 1995.

Jouzel, J., Masson, V., Cattani, O., Falourd, S., Stievenard, M., Stenni, B., Longinelli, A., Johnsen, S., Steffenssen, J., Petit, J., Schwander, J., Souchez, R., and Barkov, N. I.: A new 27 kyr high resolution East Antarctic climate record, Geophys. Res. Lett., 28(16), 3199-3202, 2001.

Kawamura, K., Parrenin, F., Uemura, R., Vimeux, F., Severinghaus, J. P., Matsumoto, K., Nakata, H., Nakazawa, T., Aoki, S., Jouzel, J., Fujii, Y., and Watanabe, O.: Northern Hemisphere forcing of climatic cycles over the past 360,000 years implied by absolute dating of Antarctic ice cores, Nature, in press, 2007.

Laskar, J.: The chaotic motion of the solar system: a numerical estimate of the size of the chaotic zones, Icarus, 88, 266-291, 1990.

Lorius, C., Jouzel, J., Ritz, C., Merlivat, L., Barkov, N., Korotkevitch, Y., and Kotlyakov, V.: A 150,000-years climatic record from Antarctic ice, Nature, 316, 591-596, 1985.

Loulergue, L., Parrenin, F., Blunier, T., et al.: New constraints on the gas age-ice age difference along the EPICA ice cores, 050 kyr, Clim. Past Discuss., 3, 435-467, 2007, http://www.clim-past-discuss.net/3/435/2007/.

Lisiecki, L. E. and Raymo, M. E: A Plio-Pleistocene Stack of 57 Globally Distributed Benthic $\delta^{18} \mathrm{O}$ Records, Paleoceanography, 20(1), PA1003, doi:10.1029/2004PA001071, 2005.

Martinson, D. G., Pisias, N. G., Hays, J. D., Imbrie, J., Moore, T. C., and Shackleton, N. J.: Age dating and the orbital theory of the ice ages: development of a high-resolution 0-300 000 years chronostratigraphy, Quat. Res., 27, 1-30, 1987.

Monnin, E., Indermuhle, A., Dallenbach, A., Fluckiger, J., Stauffer, B., Stocker, T. F., Raynaud, D., and Barnola, J.-M: Atmospheric $\mathrm{CO}_{2}$ concentrations over the last glacial termination, Science, 291(5501), 112-114, 2001

Narcisi, B., Petit, J. R., Delmonte, B., Basile-Doelsch, I., and Maggi, V.: Characteristics and sources of tephra layers in the EPICA-Dome $\mathrm{C}$ ice record (East Antarctica): Implications for past atmospheric circulation and ice core stratigraphic correlations, Earth Planet. Sci. Lett., 239, 253-265, 2005.

Narcisi, B., Petit, J.-R., and Tiepolo, M.: A volcanic marker (92 ka) for dating deep east Antarctic ice cores, Quat. Sci. Rev., 25, 2682-2687, 2006.

NorthGRIP project members: High-resolution record of Northern Hemisphere climate extending into the last interglacial period, Nature, 431, 147-151, 2004.

Parrenin, F., Remy, F., Ritz, C., Siegert, M., and Jouzel, J.: New modelling of the Vostok ice flow line and implication for the glaciological chronology of the Vostok ice core, J. Geophys. Res., 109, D20102, doi:10.1029/2004JD004561, 2004.

Parrenin, F., Dreyfus, G., Durand, G., Fujita, S., Gagliardini, O., Gillet, F., Jouzel, J., Kawamura, K., Lhomme, N., Masson-
Delmotte, V., Ritz, C., Schwander, J., Shoji, H., Uemura, R., Watanabe, O., and Yoshida, N.: 1-D-ice flow modelling at EPICA Dome C and Dome Fuji, East Antarctica, Clim. Past, 3, 243-259, 2007,

http://www.clim-past.net/3/243/2007/.

Petit, J. R., Jouzel, J., Raynaud, D., Barkov, N. I., Barnola, J.-M., Basile, I., Bender, M., Chappellaz, J., Devis, M., Delaygue, G., Delmotte, M., Kotlyakov, V. M., Legrand, M., Lipenkov, V. Y., Lorius, C., Pepin, L., Ritz, C., Saltzman, E., and Stievenard, M.: Climate and atmospheric history of the past 420000 years from the Vostok ice core, Antarctica, Nature, 399(6735), 429436, 1999.

Raisbeck, G. M., Yiou, F., Bard, E., Dollfus, D., Jouzel, J., and Petit, J. R.: Absolute dating of the last 7000 years of the Vostok ice core using ${ }^{10} \mathrm{Be}$, Mineral. Mag., 62A, 1228-1228, 1998.

Raisbeck, G. M., Yiou, F., Cattani, O., and Jouzel, J.: ${ }^{10}$ Be evidence for the Matuyama-Brunhes geomagnetic reversal in the EPICA Dome C ice core, Nature, 444(7115), 82-84, 2006.

Raisbeck, G., Yiou, F., and Jouzel, J.: Cosmogenic ${ }^{10} \mathrm{Be}$ as a high resolution correlation tool for climate records, Geochimica Et Cosmochimica Acta, 66(15A), A623, 2002.

Raisbeck, G. M., Yiou, F., Jouzel, J., and Stocker, T. F.: Direct North-South synchronization of abrupt climate change record in ice cores using beryllium 10, Clim. Past Discuss., 3, 755-769, 2007 , http://www.clim-past-discuss.net/3/755/2007/.

Rasmussen, S. O., Andersen, K. K., Svensson, A. M., Steffensen, J. P., Vinther, B. M., Clausen, H. B., Siggaard-Andersen, M.L., Johnsen, S. J., Larsen, L. B., Dahl-Jensen, D., Bigler, M., Rothlisberger, R., Fischer, H., Goto-Azuma, K., Hansson, M. E., and Ruth, U.: A new Greenland ice core chronology for the last glacial termination, J. Geophys. Res., 111, D06102, doi:10.1029/2005JD006079, 2006

Raynaud, D., Lipenkov, V., Lemieux-Dudon, B., Duval, P., Loutre, M., and Lhomme, N.: The local insolation signature of the air content in the Antarctic ice: A new step toward an absolute dating of ice records, EPSL, in press, 2007.

Reimer, P., Baillie, M., Bard, E., Bayliss, A., Beck, J., Bertrand, C., Blackwell, P., Buck, C., Burr, G., Cutler, K., Damon, P., Edwards, R., Fairbanks, R., Friedrich, M., Guilderson, T., Hogg, A., Hughen, K., Kromer, B., McCormac, G., Manning, S., Ramsey, C., Reimer, R., Remmele, S., Southon, J., Stuiver, M., Talamo, S., Taylor, F., van der Plicht, J., and Weyhenmeyer, C.: IntCal04 terrestrial radiocarbon age calibration, 0-26 cal kyr BP, RADIOCARBON, 46(3), 1029-1058, 2004.

Ruth, U., Barnola, J.-M., Beer, J., et al.: "EDML1": a chronology for the EPICA deep ice core from Dronning Maud Land, Antarctica, over the last 150000 years, Clim. Past Discuss., 3, 549-574, 2007 , http://www.clim-past-discuss.net/3/549/2007/.

Schulz, M.: On the 1470-year pacing of DansgaardOeschger warm events, Paleoceanography, 17(2), 1014, doi:10.1029/2000PA000571, 2002.

Schwander, J., Jouzel, J., Hammer, C. U., Petit, J.-R., Udisti, R., and Wolff, E.: A tentative chronology for the EPICA Dome Concordia ice core, Geophys. Res. Lett., 28(22), 4243-4246, 2001.

Severi, M., Becagli, S., Castellano, E., et al.: Synchronisation of the EDML and EDC ice cores for the last $52 \mathrm{kyr}$ by volcanic signature matching, Clim. Past, 3, 367-374, 2007, 
http://www.clim-past.net/3/367/2007/.

Severinghaus, J. P. and Brook, E. J: Abrupt climate change at the end of the last glacial period inferred from trapped air in polar ice, Science, 286, 930-934, 1999.

Shackleton, N. J.: The 100000-year ice-age cycle identified and found to lag temperature, carbon dioxide, and orbital eccentricity, Science, 289(5486), 1897-1902, 2000.

Siegenthaler, U., Stocker, T., Monnin, E., Luthi, D., Schwander, J., Stauffer, B., Raynaud, D., Barnola, J.-M., Fischer, H., MassonDelmotte, V., and Jouzel, J.: Stable Carbon Cycle-Climate Relationship During the Late Pleistocene, Science, 310, 1313-1317, 2005.

Spahni, R., Chappellaz, J., Stocker, T., Loulergue, L., Hausammann, G., Kawamura, K., Flückiger, J., Schwander, J., Raynaud, D., Masson-Delmotte, V., and Jouzel, J.: Atmospheric Methane and Nitrous Oxide of the Late Pleistocene from Antarctic Ice Cores, Science, 310, 1317-1321, 2005.

Svensson, A., Andersen, K. K., Bigler, M., Clausen, H. B., DahlJensen, D., Davies, S. M., Johnsen, S. J., Muscheler, R., Rasmussen, S. O., Röthlisberger, R., Steffensen, J. P., and Vinther, B. M.: The Greenland Ice Core Chronology 2005, 15-42 kyr. Part 2: Comparison to other records, Quat. Sci. Rev., 25, 3258-3267, 2006.

Tauxe, L., Herbert, T., Shackleton, N. J., and Kok, Y. S.: Astronomical calibration of the Matuyama-Brunhes boundary: Consequences for magnetic remanence acquisition in marine carbonates and the Asian loess sequences, Earth Planet. Sci. Lett., 140, 133-146, 1996.

Traufetter, F., Oerter, H., Fischer, H., Weller, R., and Miller, H.: Spatio-temporal variability in volcanic sulphate deposition over the past $2 \mathrm{kyr}$ in snow pits and firn cores from Amundsenisen, Antarctica, J. Glaciol., 50(168), 137-146, 2004.

Udisti, R., Becagli, S., Castellano, E., Delmonte, B., Jouzel, J., Petit, J.-R., Schwander, J., Stenni, B., and Wolff, E. W.: Stratigraphic correlations between the EPICA-Dome $\mathrm{C}$ and Vostok ice cores showing the relative variations of snow accumulation over the past $45 \mathrm{kyr}$, J. Geophys. Res., 109(D8), D08101, doi:10.1029/2003JD004180, 2004.
Vinther, B. M., Clausen, H. B., Johnsen, S. J., Rasmussen, S. O., Andersen, K. K., Buchardt, S. L., Dahl-Jensen, D., Seierstad, I. K., Siggaard-Andersen, M.-L., Steffensen, J. P., Svensson, A., Olsen, J., and Heinemeier, J.: A synchronized dating of three Greenland ice cores throughout the Holocene, J. Geophys. Res., 111, 13102, doi:10.1029/2005JD006921, 2006.

Waelbroeck, C., Jouzel, J., Labeyrie, L., Lorius, C., Labracherie, M., and Stiévenard, M.: A comparison of the Vostok ice deuterium record and series from Southern Ocean core MD 88-770 over the last two glacial-interglacial cycles, Clim. Dyn., 12(2), 113-123, 1995.

Wang, Y. J., Cheng, H., Edwards, R. L., An, Z. S., Wu, J. Y., Shen, C. C., and Dorale, J. A.: A high-resolution absolute-dated late Pleistocene Monsoon record from Hulu Cave, China, Science, 294(5550), 2345-2348, 2001.

Watanabe, O., Jouzel, J., Johnsen, S., Parrenin, F., Shoji, H., and Yoshida, N.: Homogeneous climate variability across East Antarctica over the past three glacial cycles, Nature, 422, 509512, 2003.

Wolff, E., Cook, E., Barnes, P., and Mulvaney, R.: Signal variability in replicate ice cores, J. Glaciol., 51(174), 462-468, 2005.

Wolff, E. W., Fischer, H., Fundel, F., Ruth, U., Twarloh, B., Littot, G. C., Mulvaney, R., Röthlisberger, R., de Angelis, M., Boutron, C. F., Hansson, M., Jonsell, U., Hutterli, M. A., Lambert, F., Kaufmann, P., Stauffer, B., Stocker, T. F., Steffensen, J. P., Bigler, M., Siggaard-Andersen, M. L., Udisti, R., Becagli, S., Castellano, E., Severi, M., Wagenbach, D., Barbante, C., Gabrielli, P., and Gaspari, V.: Southern Ocean sea-ice extent, productivity and iron flux over the past eight glacial cycles, Nature, 440, 491-496, 2006.

Yiou, F., Raisbeck, G. M., Baumgartner, S., Beer, J., Hammer, C., Johnsen, J., Jouzel, J., Kubik, P. W., Lestringuez, J., Stievenard, M., Suter, M., and Yiou, P.: Beryllium 10 in the Greenland Ice Core Project ice core at Summit, Greenland, J. Geophys. Res., 102, 26 783-26794, 1997.

Yuan, D., Cheng, H., Edwards, R. L., Dykoski, C. A., Kelly, M. J., Zhang, M., Qing, J., Lin, Y., Wang, Y., Wu, J., Dorale, J. A., An, Z., and Cai, Y.: Timing, Duration, and Transitions of the Last Interglacial Asian Monsoon, Science, 304(5670), 575-578, 2004. 